\title{
ОБЛАДАЛ ЛИ К. МАРКС ЭКОНОМИЧЕСКИМ ВЗГЛЯДОМ НА ХОЗЯЙСТВЕННУЮ ДЕЯТЕЛЬНОСТЬ?
}

\author{
(C) 2018 Будович Юлия Ивановна \\ доктор экономических наук, профессор Департамента экономической теории \\ Финансовый университет при Правительстве Российской Федерации \\ 125993, г. Москва, Ленинградский пр-т, д. 49 \\ E-mail: JBudovich@fa.ru
}

В настоящей статье рассматриваются причины, побуждавшие советскую политическую экономию избегать конкретики при освещении такой темы, как производственные отношения, в том числе отношения собственности, показывается, как истина в вопросе о том, кому принадлежат средства производства, приносилась в жертву политическим и идеологическим устремлениям, не взирая ни на какие социально-экономические последствия.

Ключевые слова: производственные отношения, отношения собственности, собственность на средства производства, собственность на капитал.

В советской политической экономии самой «загадочной» экономической категорией были производственные отношения, и это при том, что производственные отношения были фактически главной категорией науки, так как фигурировали в качестве ее предмета. Загадочность производственных отношений состояла в отсутствии их конкретных примеров. В учебниках давалось общее определение производственных отношений (отношения, в которые независимо от их воли и сознания вступают люди в процессе материального производства), рассказывалось, чем производственные отношения при социализме отличаются от производственных отношений при капитализме (при социализме, когда средства производства находятся в руках общества, они являются отношениями сотрудничества и взаимопомощи, тогда как при капитализме, когда средства производства принадлежать частным лицам, они являются отношениями эксплуатации человека человеком), отмечалось, что производственные отношения являются формой развития производительных сил, указывалось, что основой системы производственных отношений выступают отношения собственности на средства производства и что последние пронизывают все сферы экономических отношений (производство, распределение, обмен, потребление) и т.д., но нигде не приводились конкретные примеры производственных отношений, хотя бы отношений собственности как главных из них и поэтому в первую очередь уничтожаемых в ходе социальных революций. При этом все делали вид, что ясно себе пред-

ставляют, что такое производственные отношения, намекали, что спрашивать, что этот такое, просто неприлично. Удивительно, но в условиях, когда нельзя было оперировать примерами производственных отношений, в науке даже шла дискуссия о структуре производственных отношений социализма.

Как выясняется, туманность категорий марксистской экономической теории всегда была характерной чертой данной теории, и она отмечалась даже теми учеными, которые разделяли многие ее положения, например трудовую теорию стоимости. Как писал, например Л. Боровой в своем «Популярном курсе политической экономии» (1908): «Маркс, Энгельс и их последователи постоянно употребляют термины «производственные отношения», «способы производства», «условия производства» или «надстройка», «отражение», «рефлекс», нигде не давая их удовлетворительного объяснения, нигде не поясняя самой природы отношений между «бытием» и «сознанием», между «базисом» и «надстройкой» и т.д. и т.д. Эта уже одна невыясненность терминологии подает повод к многочисленным недоразумениям и своеобразным толкованиям доктрины» [2, с. 14]. М.И. Туган-Барановский в своих «Основах политической экономии» (1911) критикует классиков марксизма за непоследовательность в трактовке хозяйственной жизни: «Под экономическими отношениями, которые мы признаем определяющей основой общества,- пишет Энгельс в 1894 г., в одном из впоследствии опубликованных писем,- мы понимаем способ, которым люди определенно- 
го общества производят свои средства к жизни и обмениваются ими» (Documente des Socialismus, 1902, T. II, с. 73), а под средствами к жизни Энгельс понимает, как видно из его «Происхождения семейства», «пищу, одежу, жилье и необходимые для этого средства труда» (Engels, Der Ursprung der Familie, 8 изд., Предисл., с. VIII)» [3, с. 4]. Как отмечает далее М.И. Туган-Барановский, «правда, Энгельс не выдерживает этого определения и нередко сходит с его почвы. Производство товаров следует считать, с точки зрения Маркса и Энгельса, безусловно хозяйственной деятельностью, но товарами являются предметы, удовлетворяющие далеко не одним необходимым потребностям жизни. Библия в известном примере Маркса в I томе «Капитала» есть такой же товар, как и холст или водка» [3, с. 4]. При этом после перехода в нашей стране на рубеже 20-30-х гг. $\mathrm{XX}$ в. к марксистско-ленинской политической экономии советские толкователи марксизма разъяснили его основные понятия (способ производства, надстройка и т.д.), но термин «производственные отношения» так и оставили загадкой [4] [5]. Выяснению конкретного содержания данного понятия, прежде всего отношений собственности, и причин, побуждавших регулятора советской политической экономии его скрывать, и посвящается данная статья.

Подходом к решению поставленных задач является общепризнанное положение, что языком экономики является бухгалтерский учет [6]. М.С. Атлас и К.Н.Лебедев в статье «К вопросу о содержании экономических понятий» (2000) фактически показали, что содержание экономических понятий, используемых для изучения деятельности предприятия, образуют приходы и расходы средств предприятия (его активов) и их источников (его пассивов), а также их запасы [7]. Первые образуют содержание бухгалтерской отчетности, характеризующей объемы деятельности предприятия в течение отчетного периода, а вторые образуют содержание бухгалтерского баланса, характеризующего состояние предприятия на конец периода. Таким образом, экономическую картину деятельности хозяйства, или предприятия, дают бухгалтерские отчетность и баланс или, по-другому, экономист видит хозяйственную деятельность в виде бухгалтерских отчетности и баланса. Очевидно, что с помощью отчетности и баланса можно продемонстрировать отличие экономического взгляда на предприятие от технического взгляда на него, т.е. взгляда, характерного для техника. В соответствующих целях, в виду его большей простоты, используем только баланс. В табл. 1 представлен бухгалтерский баланс предприятия (без цифровых данных), в котором жирным и курсивом выделены позиции, доступные взгляду техника.

Таким образом, техник не увидит в хозяйственной деятельности все пассивы предприятия и такой его актив, как задолженность предприятию, или, по-другому, увидит только реальные ценности предприятия, но не фиктивные. Это объясняется тем, что технические работники, в том числе кассир, отвечающий за хранение денег предприятия, не осуществляют расчетов с организациями, с которыми связано предприятия. А именно при осуществлении расчетов (с покупателями, учредителями, банками-кредиторами, продавцами) у предприятия и возникают фиктивные ценности.

Теперь будет легко ответить на вопрос, обладал ли К. Маркс экономическим взглядом на хозяйственную деятельность, законы которого пытался установить? В работе К.Н. Лебедева «Почему модель кругооборота капитала К. Маркса так и не стала теорией бухгалтерского учета» (2015) показано, что Марксова модель кругооборота капитала «Деньги - Товар (средства производства, рабочая сила)... Производство... Товар штрих (готовая продукция) - Деньги штрих» (Д - Т (Сп, Рс) ...П... Т’ - Д’) не стала моделью деятельности по бухгалтерскому учету прежде всего потому, что в ней не представлена такая

Таблица 1. Бухгалтерский баланс, и его часть, которую видит техник

\begin{tabular}{|l|l|}
\hline \multicolumn{1}{|c|}{ АКТИВ } & \multicolumn{1}{|c|}{ ПАССИВ } \\
\hline Средства труда & Капитал \\
\hline Предметы труда & Прибыль \\
\hline Незавершенное производство & Кредиты полученные \\
\hline Готовая продукция & Задолженность предприятия \\
\hline Деньги & \\
\hline Задолженность предприятию & \\
\hline
\end{tabular}

Источник: составлено автором. 
обязательно представленная на предприятии форма стоимости, как имущество капиталиста, которая уменьшается при вложении капиталистом средств в предприятие, в том числе в форме нераспределенной прибыли, и увеличивается при изъятии вложенных в бизнес средств и распределении прибыли. Данная форма стоимости, т.е. имущество капиталиста, как раз и получает отражение в пассиве баланса, т.е. является пассивами предприятия (капитал и прибыль). В модели нет и форм стоимости, соответствующих другим фиктивным ценностям, образующим активы или пассивы предприятия [8, с. 49]. Соответственно, все представленные в Марксовой модели кругооборота капитала формы стоимости, а именно денежная, товарная и производственная, относятся исключительно к реальным ценностям. В связи с этим, как отмечается в рассматриваемой статье, модель кругооборота капитала в действительности является моделью кругооборота не капитала, а средств, вложенных в деньги предприятия [8, с. 49]. Никакого капитала в этой модели не представлено. Таким образом, судя по модели кругооборота капитала, можно утверждать, что К. Маркс не обладал экономическим взглядом на хозяйственную деятельность, так как не замечал фиктивных ценностей предприятия, образующих его пассивы и частично - активы.

Подтверждает вывод об отсутствии у К. Маркса экономического взгляда на хозяйственную деятельность, сделанный на основе сравнения форм стоимости, представленных в его модели кругооборота капитала, с формами стоимости, получающими отражение в бухгалтерском балансе, и сведения о знании К. Марксом бухгалтерского учета, в котором составляется баланс. Целая глава книги К.Ю.Цыганкова «Очерки теории и истории бухгалтерского учета» (2007) посвящена исследованию познаний в области бухгалтерского учета классиков марксизма, в том числе на основе изучения их переписки по данному вопросу, в которой К. Маркс задает коммерсанту Ф. Энгельсу разные вопросы, касающиеся ведения бухгалтерского учета, а Ф. Энгельс никак не может на них ответить, и оба признаются в слабом понимании сути бухгалтерии. Так, по вопросу о фонде возмещения основного капитала Ф. Энгельс обещает прислать К. Марксу расчеты и признается: «Что же касается экономического значения этого дела, то оно мне не совсем ясно» [9, с. 308]. Из всего этого он делает следующий вывод: «... И К. Маркс, и Ф. Энгельс, даже не имея практического опыта, могли, работая с литературой совершенно самостоятельно, быстро ухватить суть любой науки и технологии, составить о ней независимое, самостоятельное мнение, публиковать и успешно отстаивать его в дискуссиях с профессионалами. Бухгалтерия стала для них исключением...» [9, с. 309]. Таким образом, исследование К.Ю. Цыганкова подтверждает сделанный ранее вывод о том, что К. Маркс не обладал экономическим взглядом на хозяйственную деятельность.

Как было показано выше, отсутствие экономического взгляда на хозяйственную деятельность фактически означает, что соответствующее лицо не видит такой части экономической реальности, как пассивы. Это значит, что понятия или термины, используемые для характеристики пассивов, он применяет к активам, в связи, с чем возникает терминологическая путаница. Ярким примером такой путаницы является применение к активам названия «Капитал», служащего для обозначения определенных пассивов. Соответствующее неправильное словоупотребление как раз имело место в переписке между К. Марксом и Ф. Энгельсом по вопросам ведения бухгалтерского учета. В ней фонд возмещения основных средств, или средств труда, именуется классиками марксизма фондом возмещения основного капитала, т.е. основные средства они путают с основным капиталом. Об этой распространенной путанице, характерной, кстати, для ученых-экономистов, писал американский экономист Дж.Б. Кларк в знаменитом произведении «Распределение богатства» (1899): «Капитал делится на основной и оборотный. Этими терминами обычно обозначаются различные части перманентного фонда истинного капитала, а не два вида капитальных благ; и обычная мысль и разговорная речь чаще всего употребляют их в этом смысле... Но в научном использовании эти термины употребляются для выражения двух разновидностей капитальных благ. И здесь в результате снова получается известная путаница... Определенные виды средств производства, как нам говорят экономисты, являются основным капиталом, а некоторые другие вещи - оборотным капиталом. Строения, машины и т.п. представляют первый род; сырье, полуфабрикаты и т.д.- последний» [10, с. 126]. Собственно говоря, само название модели «Модель кругооборота капитала» говорит о том, что ее автор понимал под 
капиталом средства и предметы труда, товары и деньги.

Далее мы вплотную приближаемся к разгадке тайны производственных отношений, включая отношения собственности. Те отношения собственности при капитализме, которые имеют социальное содержание и уничтожаются в результате пролетарской революции, получают отражение в пассиве баланса. Это отношения собственности на капитал, который, будучи внесенным в предприятие капиталистами в виде учредительских взносов или ссуд, становится долгом предприятия, т.е. образует его пассив. К. Маркс, как было показано выше, видел только актив предприятия и, следовательно, только те отношения собственности, которые получают отражение в активе баланса. А это отношения собственности предприятия на принадлежащие ему основные средства, материалы, готовую продукцию, деньги и т.д., т.е. отношения собственности предприятия на средства производства. В связи с тем, что К. Маркс видел только актив предприятия, то понятие «собственность на капитал» ассоциировалось у него с собственностью предприятия на средства производства. В связи с этим К. Маркс говорил об изъятии у капиталистов не вкладов и взносов в предприятия, а именно средств производства, как расшифровывалось понятие «экспроприация экспроприаторов» [11]. Поэтому, приводя примеры отношений собственности, советским политэкономам пришлось бы приводить примеры приобретения, владения и распоряжения предприятиями своими активами, которые не имеют никакого отношения к тому, что получают в собственность, чем владеют и распоряжаются капиталисты. Но в этом случае вскрылось бы несоответствие марксистско-ленинской политической экономии экономической реальности и, соответственно, экономическое невежество К. Маркса. Теперь ясно, и почему не приводились примеры других производственных отношений. Дело в том, что отношения приобретения предприятиями реальных активов (средств производства, рабочей силы, товаров и денег), владения и распоряжения ими, как раз и являются прочими производственными отношениями. Если бы они приводились в качестве примеров таковых, то закономерно встал бы вопрос, а чем они отличаются от отношений собственности, которые также, по Марксу, являются отношениями приобретения, владения и распоряже- ния реальными активами предприятия?

Конечно же, регулятор советской политической экономии еще при переходе на марксистско-ленинскую политическую экономию, мог поправить К. Маркса, несмотря на то, что революционные лозунги марксизма были изложены в терминах средств производства. К. Маркс и Ф. Энгельс неоднократно именно поправлялись, а не уточнялись или прояснялись, например, что касается сфер общественного производства, производственные отношения в которых изучает политическая экономия. Как писал К. Маркс в «Капитале» (1867), «предметом моего исследования в настоящей работе является капиталистический способ производства и соответствующие ему отношения производства и обмена» [12, с. XXXII]. В курсе же лекций «Политическая экономия - теоретическая основа революционной борьбы рабочего класса» под ред. Л.И. Абалкина (1983) отмечается: «Специфическим предметом политической экономии являются производственные отношения, т.е. отношения по поводу производства, распределения, обмена и потребления материальных благ в человеческом обществе, образующие экономический строй общества на различных этапах его развития» [13, с. 17]. Таким образом, к производству и обмену как объектам познания науки, по Марксу, добавились обмен и потребление. Почему же очевидная ошибка К. Маркса не была исправлена?

Дело в том, что подмена собственности капиталистов на капитал их собственностью на средства производства была положена в основу выведенного К. Марксом главного противоречия капиталистического общества, которым выступает противоречие между общественным характером производства и частнособственническим характером присвоения, т.е. якобы продукция производится коллективным трудом, но присваивается капиталистом. В действительности произведенная продукция принадлежит не капиталисту, а предприятию, а собственник предприятия, как и наемный работник, не имеет права распорядиться произведенной продукцией по своему усмотрению, например, забрать себе домой часть готовой продукции со склада предприятия, и это всем известно. Но сказать, что капиталисту, как и наемному работнику, произведенная предприятием продукция не принадлежит, что капиталист владеет лишь фиктивными ценностями, а именно капиталом и прибылью, значит отрицать главное противоре- 
чие капитализма. Таким образом, соответствующая поправка К. Маркса фактически означала бы разрушение одного из главных доказательств скорой и неизбежной смены капиталистических производственных отношений социалистическими, на что регулятор марксистско-ленинской политической экономии пойти не мог, так как СССР периодически проводил политику экспорта пролетарской революции, например в 19191937 гг. [14].

В заключение рассмотрим одно роковое последствие отсутствия у К. Маркса экономического взгляда на хозяйственную деятельность. В связи с тем, что К. Маркс смешивал собственность на капитал с собственностью на средства производства, в теории революционной борьбы рабочего класса экспроприация собственников предприятий стала смешиваться с экспроприацией администрации предприятий, прежде всего их высшего руководства, олицетворявшего собственность предприятий на средства производства. Эта коренная ошибка теории революции привела к тому, что администрация предприятий, прежде всего крупных, в период национализации отраслей народного хозяйства в СССР выступила на стороне собственников, поддерживая их политику закрытия предприятий. Так, известно, что на петроградской фабрике «Пекарь» в 1918 г. администрация тормозила работу, подготавливала голодный бунт в подрайоне, неоднократно заявляла о расчете рабочих из-за того, что нет средств им платить [15]. Если бы теория революции отделяла собственников предприятий от администрации предприятий, то последняя, состоящая в большинстве своем из наемных работников, гораздо более позитивно восприняла бы идею социалистической революции, и разруха народного хозяйства, вызванная Первой мировой войной и Октябрьской революцией 1917 года, не была бы столь глубокой и была бы преодолена значительно быстрее.

\section{Библиографический список}

1. Румянцев А. М., Козлов Г.А., Милейковский А.Г. и др. Капиталистический способ производства. Т. 1. // Политическая экономия. Москва. 1977. 608 с.

2. Боровой А. Популярный курс политической экономии. Москва. 1908. 326 с.

3. Туган-Барановский М.И. Основы политической экономии. Санкт-Петербург. 1911. 510 [XI] с.

4. Будович Ю.И. Марксистская трактовка предмета науки как производственных отношений и ее недостатки // Проблемы развития современного общества: экономические, правовые и социальные аспекты. Сб. науч. статей по итогам Всероссийской научно-практической конференции. Под редакцией И.Е. Бельских, А.Ф. Московцева. 2014. С. 57-63.

5. Будович Ю.И. Причины популярности трактовки предмета как производственных отношений в российской политической экономии на рубеже XIX-XX вв. // Экономические науки. 2014. № 117. С. 47-52.

6. Мезенцева В. Почему бухгалтерский учет называют языком бизнеса? [Электронный pecypc] / URL: http://copdoc.ru/articles/673.html.

7. Атлас М. С., Лебедев К.Н. К вопросу о содержании экономических понятий // Вестник Финансовой академии. 2000. № 3. С. 5-15.

8. Лебедев К.Н. Почему модель кругооборота капитала К. Маркса так и не стала теорией бухгалтерского учета // Международный бухгалтерский учет. 2015. № 1 (343). С. 43-52.

9. Ц Цыганков К.Ю. Очерки теории и истории бухгалтерского учета. Москва. 2007. 462 с.

10. Кларк Дж.Б. Распределение богатства. Москва. 2000. 368 с.

11. Большая советская энциклопедия. Экспроприация экспроприаторов [Электронный pecypc] / URL: http://alcala.ru/bse/izbrannoe/slovar-EA/EA10631.shtml

12. Маркс К. Капитал. Критика политической экономии. Т. 1. Книга 1. Процесс производства капитала. МоскваЛенинград. Государственное издательство, 1930. [XLVI] 621 с.

13. Политическая экономия - теоретическая основа революционной борьбы рабочего класса: курс лекций / Под ред. Л.И. Абалкина. Москва. 1983. 512 с.

14. Коммунистический интернационал. Трети и последний / Вопросы CСCP. Ussrvopros. ru URL: http://ussrvopros. ru/politika-sssr/sovetskij-stroj/266-kommunisticheskij-internatsional-tretij-i-poslednij.

15. Рабочий контроль [Электронный ресурс] / URL: https://studfiles.net/preview/4349302/page:31/. 